\title{
Rank Dependent Utility, Tax Evasion and Labor Supply
}

\author{
Erling Eide \\ Kristine von Simson \\ Steinar Strøm
}

CESIFO WORKING PAPER NO. 3213

CATEGORY 4: LABOUR MARKETS

OCTOBER 2010
An electronic version of the paper may be downloaded
- from the SSRN website:
- from the RePEc website:
- from the CESifo website:
www.SSRN.com
www.RePEc.org
www.CESifo-group.org/wp




\title{
Rank Dependent Utility, Tax Evasion and Labor Supply
}

\begin{abstract}
In the simple Allingham-Sandmo portfolio model of tax evasion an expected utility maximizer will cheat more than what is estimated in empirical studies. Two main types of explanation have been suggested as solutions to this puzzle: (1) Tax payers act according to some non-expected utility theory, and (2) Individual ethical norms and social stigma induce people not to cheat. In the present study we test two hypotheses within these broad explanations: (1) Tax payers are weighting subjective probabilities of being penalised according to the rank dependent utility theory, and (2) Tax payers' beliefs about social norms have an effect on their decision to evade taxes. Our model is characterized by a simultaneous determination of tax evasion and labour supply, including the effect on tax payers of a social norm of not cheating. Using Norwegian survey data our hypotheses are corroborated. Our estimates imply that if the objective probability of being penalized is, say $3 \%$, the weighted probability is about $23 \%$. Our study provides an independent confirmation of the rank dependent expected utility theory. The model explains data $53 \%$ better than pure random choices and predicts hours worked in the regular economy, among tax evaders as well non tax evaders, rather precisely. The model is an example of a two sector choice model and the results indicate that an overall wage increase may shift labor supply away from the irregular part of the economy towards the regular.
\end{abstract}

JEL-Code: C25, D12, D81, H26, J22.

Keywords: labor supply, tax evasion, rank dependent utility.

Erling Eide

University of Oslo and the Frisch Centre

Oslo / Norway

erling.eide@jus.uio.no
Kristine von Simson

Institute for Social Research

Oslo / Norway

kristine.von.simson@samfunnsforskning.no

Steinar Strøm

University of Oslo and the Frisch Centre

Oslo / Norway

steinar.strom@econ.uio.no

September 20, 2010

We acknowledge the support from Norwegian Tax Authority and the Research Council of Norway. We are grateful for very helpful comments and suggestions from three anonymous referees. 


\section{Introduction}

In the literature of tax evasion it has been considered a puzzle that people seem to cheat less than suggested by the expected utility theory. According to Allingham and Sandmo's (1972) portfolio choice approach to income tax evasion, a risk-averse tax payer, with a von Neumann-Morgenstern utility function, will under-report his income whenever the tax rate is greater than the expected penalty rate. Intuition as well as empirical evidence seems to contradict this conclusion. For the more common types of tax evasion the sanctions in many countries consist of fines less (or not much higher) than the amount evaded, whereas the probabilities of tax returns being audited are of the order of a few percent. ${ }^{5}$ In general, expected utility maximizers would, therefore, be tax evaders, a result that is not supported by empirical evidence. ${ }^{6}$

One reason for the discrepancy might be that the tax payers' subjective probability of audit is considerably higher than the observed objective probability. ${ }^{7}$ A related explanation is that people are weighting objective or subjective probabilities of sanctions. Another reason might be social norms producing shame and stigma. Our empirical study includes tests of these two. A third reason is lack of time and opportunities to work in the irregular part of the economy.

Although a number of models allow for weighting of probabilities, a phenomenon observed in many laboratory experiments, models based on simple weighting of probabilities violate stochastic dominance. In the RDEU model, initially developed by

\footnotetext{
${ }^{5}$ Tax authorities are somewhat reluctant to supply information about the (low) values of probabilities of being audited and sanctioned. According to Marchese and Privileggi (1997), p. 400) the audit rate in Italy in 1991 and 1994 was about 1 per cent. In the US the audit rate decreased from 4.75 per cent in 1965 to 0.8 per cent in 1990, and increased to 1.9 per cent in 1995 (Feinstein 1998, p. 576) The penalty rate in the US is about 50 per cent of the tax evaded. Thus, in the early 1990ies, the expected value per dollar of evaded tax was almost equal to 0.99 dollar.

${ }^{6}$ See the review of Andreoni et al. (1998) for references and discussion. For any sensible value of the risk aversion parameter taxpayers should report either a small proportion of their income or none whatsoever (Feinstein 1999, p. 576). In spite of the apparent profitability of tax evasion, the comprehensive Taxpayer Compliance Measurement Program in the US found that about 40 per cent of the tax payers underpaid their taxes (Feinstein 1998, F361). Various studies of the underground economy conclude that in Western countries somewhere between 2 and 30 per cent of the BNP is not reported to the tax authorities. (Schneider and Enste 2000). Note that some authors report the income evaded and others the tax evaded, $\mathrm{cf}$ note 5. The difference is related to the difference between the model of Allingham and Sandmo (1972) and that of Yitzhaky (1974).

${ }^{7}$ This discrepancy is documented in a Slemrod's (1992) comprehensive survey of experimental and empirical literature on tax evasion.
} 
Quiggin (1982), the linearity of probabilities of the EU model is replaced by a probability weighting function which assigns weights to the probabilities of the different states of nature. The weights themselves are functions of the rank of a given state of nature, where the rank is determined by the individual level of satisfaction obtained in the various states. Since in the RDEU model it is the cumulative distribution function that is transformed, stochastic dominance is assured (Quiggin 1982). The cumulative prospect theory of Tversky and Kahneman (1992) has also this property, and that model has the additional property of allowing for different weighting functions for losses and for gains, a property that has some attraction in studies of tax evasion. Perhaps less attractive in a study of tax evasion is the assumption in the cumulative prospect theory that only changes in wealth, and not its absolute value, matters.

The RDEU model is among the strongest contenders to the EU model (see e.g. Weber and Kirsner (1997)). Examining a number of empirical studies, Hey and Orme (1994) concludes that among a great number of utility functionals the RDEU function is found to be the best. ${ }^{8}$ Empirical support for the RDEU model has been obtained by Lopes (1987, 1990), Cho, Luce, and von Winterfeldt (1994), and Chung, von Winterfeldt, and Luce (1994). ${ }^{9}$

A number of studies indicate that the weighting function in the RDEU model has the form of an inverted S-shaped curve. Empirical support for this shape is found i.a. in several choice studies. ${ }^{10}$ A particular reason for employing the RDEU model is the theoretical study by Arcand and Rota Graziosi (2005) demonstrating that the RDEU model provides a compelling answer to the above mentioned puzzle of over-

\footnotetext{
${ }^{8}$ Hey and Orme (1994, p. 1321) conclude their examination thus: "Expected utility theory (and its special case, risk neutrality) emerges from this analysis fairly intact. For possibly $39 \%$ of the subjects ... EU theory appears to fit no worse than any of the other models ... For other $67 \%$ of the subjects, one or more of the eight "top-level" functionals ... fits significantly better in statistical terms, though often the economic significance is not all that great. Of the eight "top level" functionals it would appear that the two rank dependent functionals and the quadratic utility model emerge as the strongest contenders (with the Quiggin weighting functional having a models lead over its power weighting function rival)".

${ }^{9}$ See, however, discussions in Wakker et al. (1994), and Birnbaum et al. (1999) of various weaknesses of the RDEU model.

10 "Empirical support for this specification comes from a wide range of studies. ...Collectively, these studies show that models with s-shaped probability transformations offer significant predictive improvement over EUT and outperform other rivals." Starmer (2000, p. 359). For examples, see Camerer and Ho (1994), Tversky and Kahneman (1992), Wu and Gonzales (1996), Gonzales and Wu (1999), and, for a survey, Camerer (1995).
} 
compliance. ${ }^{11}$ The weight a person gives to the uncertainty of events may for several reasons differ from the objective probabilities. People may (i) form (deterministic) subjective probabilities, (ii) weigh objective probabilities, (iii) weigh subjective probabilities, or (iv), weigh probabilities due to ambiguity or uncertainty about subjective or objective probabilities. The present empirical study is based on subjective probabilities. The estimate of the parameter $a$ below indicates that people transform these subjective probabilities. The study cannot, however, distinguish between a weighting of given subjective probabilities and a weighting caused by the uncertainty or vagueness of the objective probabilities. In studies of ambiguity, i.e. in studies where objective probabilities are absent, Gilboa (1987) and Schmeidler (1989) have (seemingly independently) come up with the RDEU model. In these studies, the decision weights are interpreted as non-additive subjective probabilities. In the standard RDEU model developed by Quiggin (1993) objective probabilities are assumed known. These probabilities are then transformed by non-additive decision weights. 1213

In recent years a growing number of studies have suggested that tax compliance depends on individual and social norms, and also that individual norms are influenced by social norms. ${ }^{14}$. By social norms are usually meant moral standards attributed to a social group or collective (Wenzel, 2004). Some authors rather emphasize the effect of social customs. There might be several reasons for a tendency to internalize social norms of tax compliance. One reason might be that people have a general wish of behaving according to society's rules, a conformity attitude. Tax law should be adhered to even if one disagrees with the specific rules (Henrich 2004). Another reason might be that people consider it right to act equally (ir)responibly as their fellow citizens, a reciprocity attitude (Rabin, 1998, and Falk and Fehr, 2002). Behavior will then be characterized by

\footnotetext{
${ }^{11}$ Dhami and al-Nowaihi (2007) demonstrates that the cumulative prospect theory of Tversky and Kahneman (1992) provides a satisfactory account of tax evasion, including an explanation of the Yitzhaki puzzle, than expected utility theory

${ }^{12}$ It is worth noticing that Allais in his 1953 article comes up with the RDEU model. Discussing the independent works of Quiggin (1982), Yaari (1987), and Segal (1987), he states in his Nobel prize lecture in 1988: "It is very significant that, starting from entirely different premises, all three authors have been led to a mathematical formulation that is analogous to my own".

${ }^{13}$ Some attempts to model this distinction appear in Fox and Tversky (1998), and Wu and Gonzales (1999). Kilka and Weber (2001) provide estimates of both probability judgements and probability transformations. ${ }^{14}$ Of course, the idea that individual norms of tax evasion might be influenced by social norms is not new, see e.g. Kelman (1958).
} 
conditional cooperation (Frey and Torgler 2007). People will tend to comply only to the extent that other people comply.

Breaching ones' own individual norms might cause guilt, whereas breaching a social norm or custom might produce shame and stigma. Guilt and shame might produce "psychic costs" (Gordon 1989), and stigma might produce more direct costs reducing the utility of the tax payer. Several empirical studies corroborate these ideas. In their classical field experiment Schwartz and Orleans (1967) found that tax payers who were remined that compliance is a moral duty reduced evasion more than those who were informed that evasion might be sanctioned. Grasmick and Scott (1982) concluded that guilt had a stronger effect than stigma and legal punishment. A number of more recent studies indicate that internalized norms increase tax compliance (e.g. Hasseldine and Kaplan, 1992; Erhard and Feinstein, 1994; Reckers, Sanders and Roark, 1994).

In the social custom literature it is usually assumed that a person obtains utility by behaving in accordance with a social custom, a utility that is lost if tax evasion (of any amount) is undertaken. In addition, as Myles and Naylor (1996) assume, there is a conformity payoff that depends on the size of the conforming population.

It is not our purpose to distinguish between these various explanations of why social norms or customs might have an effect on the behavior of tax payers. Our goal is to carry out a simultaneous test of the deterrence hypothesis of an RDEU model of tax compliance (Bernasconi 1998, Eide 2003) and the hypothesis that an individual tax payer is influenced by his or her assessment of the social norm of tax compliance.

Our results indicate that people are exaggerating the probability of being sanctioned for tax evasion. In addition, they are overweighing this probability, possibly because of the uncertainty or ambiguity of the subjective (and objective) probability. We also find that tax evasion depends on individual tax payers' assessment of the social norm of tax compliance. Thus, stigma and overweighting of probabilities might explain the "tax evasion puzzle". 15

We also allow for rational behavior in the form of utility maximization under budget constraints, together with random elements, to play a role in explaining labor supply

\footnotetext{
${ }^{15}$ Using various parameter estimates from other studies, Dhami and al-Nowaihi (2007) show that the "tax evasion puzzle" can be explained within a prospect theory framework.
} 
when tax evasion is an option. It is left to the data to determine the importance of the different elements. In this respect we deviate from the approach to economic research hinted at in Elster (1989) where it seems that norms are alternatives to rational choice behavior rather than a supplement.

The empirical results imply that economic incentives matter with respect to the labor supply when working in the shadow economy is an option. The model explains data $53 \%$ better than if all choices had been made at pure random.

The labor supply elasticities imply that an overall wage increase may shift labor supply away from the irregular economy towards the regular economy. This also means that when there is a negative shock that hits employment and wages, labor supply may increase in the irregular part of the economy.

The paper is organized as follows. Section 2 presents the model. A labour supply model permitting people to evade tax or to be honest is estimated by use of data from a survey carried out by a Norwegian polling institute. In a first stage, a person is assumed to choose to be an evader or not. In a second stage, the person will decide on the number of working hours, given the decision of evading taxes or not. It should be noted that we employ a random utility framework. The reason why is that we do not observe all attributes of a choice that affect preferences. Hence our dependent variables will not be deterministic variables like hours of work, but probabilities of being a tax evader or not, and the probability of working certain hours. Our model is an example of a two sector choice model and to our knowledge this is the first attempt to analyse tax evasion based on a structural econometric model approach.

Sections 3 and 4 give the data and estimation results, respectively. Section 5 report labor supply elasticities and Section 6 concludes. 


\section{The model}

\subsection{Introduction}

The purpose of our analysis is to estimate a labor supply model when tax evasion is an option. This implies that we are able to tests hypotheses with regards to how labor supply respond to changes in wages, exogenous income and tax rates. In our model we are able to present labor supply responses when tax evasion is an observed option. In this way we are able to control for something that otherwise is ignored when labor supply models are estimated. What otherwise has to be treated as unobserved heterogeneity in the choice sets are here included in the model. The model is an example of a two sector choice model where the two sectors are the regular and the irregular part of the economy.

We will assume that the individual decides in two stages. In the first stage he or she decides whether to be honest $(\mathrm{H})$ or to be a tax evader $(\mathrm{E})$. We will assume that the individual chooses the strategy that gives him, or her, the highest utility.

Tax evasion is a risky activity. There is a probability that a tax evader will be caught if taxes are evaded and we thus assume that the individual makes his or her tax evasion decision under uncertainty. As mentioned in the introduction we extend the approach of Allingham and Sandmo (1972) by allowing for the possibility that the individual deviates from the expected utility behavior by giving overweight to small probabilities that are related to undesirable events, see Kahneman and Tversky (1979).

In the second decision stage, the individual decides on how many hours to work, given the strategy of being honest or not. If he or she follows an evasion strategy, part of the wage income is not declared to the authorities. A tax evader may in part earn wage income that is declared to the tax authorities and in part wage income that is not declared. Thus, an individual who follows the evasion strategy may work in the regular as well as in the irregular part of the economy. A person following an honest strategy works of course only in the regular part of the economy.

There have been previous attempts to estimate tax evasion models based on micro data. In Lacroix and Fortin (1992) a quadratic utility function is applied together with 
budget constraints to generate labor supply functions for the regular and the irregular labor market. Agents are assumed to decide under uncertainty, given probabilities for being caught and fines if detected. The model is made stochastic by assuming that one of the parameter in the utility function is random. Labor supply functions are derived from applying a marginal criteria approach. The model is estimated on Canadian survey data.

Lemieux, Fortin and Frechette (1994) apply the same data set to estimate a similar labor supply model. Labor supply in the regular and irregular part of the economy is estimated, including the participation rate in tax evading activities. The utility function is assumed to be quasi-linear and separable in consumption and leisure. The model is made random by assuming that a parameter in the budget constraint is random. Again, labor supply functions are derived from applying a marginal criteria approach.

In contrast to the two previous contributions we assume a random utility model with extreme value distributed utilities. The specification of the deterministic part of the utility function is a Box-Cox transformation of consumption and leisure. This specification allows us to check whether the estimated utility function is quasi-concave for all individuals, which is not so easily done with polynomial forms. The Box-Cox utility function is rather flexible with linear and log-linear utility functions as special cases. Moreover, our specification of the budget constraints takes into account all details of the tax structure. The marginal tax rates are not uniformly increasing with income (Appendix 2 ) and hence, the budget set is non-convex. The latter implies that marginal criteria cannot be applied to generate labor supply decisions and in our model the agents are assumed to compare utilities across all alternatives when making their decisions. Moreover, because all details of the tax functions are accounted for, we are able to use the model, once estimated, to simulate the outcome of different tax structures. Finally, and in contrast to the previous work in this field, we allow for a weighting of the detection probability and we let perception of social norms play a role in explaining behavior.

Our model is a random utility model and with choice probabilities as the outcome of the model. These probabilities are input in the joint likelihood that gives the ex-ante joint probability of the observed choices made by the individuals in the sample. By maximizing this joint likelihood with respect to the unobserved parameters of the sample 
we let the observed choices has the highest chance to occur (maximum likelihood estimation). The theoretical model is the same as the empirical model and is an example of structural econometric modeling.

\subsection{A two stage model.}

To explain the model we start with the last decision stage, stage2. Here we model the choices, given the decision of the individual to be an evader or not.

\section{Stage2. Given an honest strategy}

Let

$\mathrm{C}_{\mathrm{iH}}=$ after tax wage income when the individual follows an honest strategy $(\mathrm{H})$ and $\mathrm{h}_{\mathrm{iH}}=$ annual hours; $i=1,2,, n$, where $n$ is the number of categories of hours. When $i=1$, the individual does not work.

Let

$\mathrm{W}_{\mathrm{H}}=$ hourly wage rate in the regular economy

$\mathrm{R}_{\mathrm{iH}}=$ gross annual wage income $=\mathrm{W}_{\mathrm{H}} \mathrm{h}_{\mathrm{iH}}$

$\mathrm{I}=$ non-wage income

$\mathrm{T}\left(\mathrm{R}_{\mathrm{iH}}, \mathrm{I}\right)=$ taxes paid as a step-wise linear function of wage income and non-wage income. Thus

(1) $\mathrm{C}_{\mathrm{iH}}=\mathrm{R}_{\mathrm{iH}}+\mathrm{I}-\mathrm{T}\left(\mathrm{R}_{\mathrm{iH}}, \mathrm{I}\right) ; \mathrm{i}=1,2,, \mathrm{n}$

Let $\mathrm{U}_{\mathrm{iH}}$ be the utility when the individual follows an honest strategy and works $h_{\mathrm{iH}}$ hours and let $\mathrm{X}$ be a vector of socio-demographic characteristics. Moreover, $\varepsilon_{\mathrm{iH}}$ is a random variable, assumed to be extreme value IID distributed with zero mean and a constant variance.

Thus

(2) $\mathrm{U}_{\mathrm{iH}}=\mathrm{u}\left(\mathrm{C}_{\mathrm{iH}}, \mathrm{h}_{\mathrm{iH}}, \mathrm{X}\right)+\varepsilon_{\mathrm{i}} ; \mathrm{i}=1,2,, \mathrm{n}$ 
$\mathrm{u}($.$) is the deterministic part of the utility function and \varepsilon_{\mathrm{i}}$ is the random part. The random part may be known to the individual but not to the outside observer. The total utility, the sum of the random and the deterministic part, is an ordinal utility function.

Let $\mathrm{S}_{\mathrm{H}}$ denote the expected value of the max of the utility function. As demonstrated in Ben-Akiva and Lerman (1985), $\mathrm{S}_{\mathrm{H}}$ is given by

(3) $\mathrm{S}_{\mathrm{H}}=\mathrm{E}\left[\max _{\mathrm{i}=1,2,, \mathrm{n}} \mathrm{U}_{\mathrm{iH}}\right]=\mu_{2} \ln \sum_{\mathrm{k}=1}^{\mathrm{n}} \exp \left(\mathrm{u}_{\mathrm{kH}} / \mu_{2}\right)$

Unobserved heterogeneity in preferences is represented by a single constant $\mu_{2}$. The more uncertain the preferences are, the larger this constant is. $\mathrm{S}_{\mathrm{H}}$ can also be interpreted as the expected indirect utility function associated with the $\mathrm{n}$ (regular) alternatives

The probability of choosing $\mathrm{h}_{\mathrm{iH}}$ hours, conditional on the honest strategy, is given by

(4) $\mathrm{P}\left(\mathrm{h}_{\mathrm{iH}} \mid \mathrm{H}\right)=\mathrm{P}\left(\mathrm{U}_{\mathrm{iH}}=\max _{\mathrm{k}=1,2, \ldots \mathrm{n}} \mathrm{U}_{\mathrm{kH}}\right)$.

With $\varepsilon_{\mathrm{i}}$ being extreme value IID distributed it is well known that this optimal choice probability $\mathrm{P}\left(\mathrm{h}_{\mathrm{iH}} \mid \mathrm{H}\right)$ is a multinomial logit. This multinomial logit can be derived from taking the derivatives of the consumer surplus $\mathrm{S}_{\mathrm{H}}$ with respect to the deterministic part of the utility function (see Anderson et al (1992), chapter 2, for this and other aspects of discrete choice models with random preferences):

(5) $\mathrm{P}\left(\mathrm{h}_{\mathrm{iH}} \mid \mathrm{H}\right)=\frac{\partial \mathrm{S}_{\mathrm{H}}}{\partial \mathrm{u}_{\mathrm{iH}}}=\frac{\exp \left(\mathrm{u}_{\mathrm{iH}} / \mu_{2}\right)}{\sum_{\mathrm{k}=1}^{\mathrm{n}} \exp \left(\mathrm{u}_{\mathrm{kH}} / \mu_{2}\right)} ; \mathrm{i}=1,2,,, \mathrm{n}$

We note that in (5) $\mu_{2}$ appears only as a scaling coefficient of the deterministic part of the utility function. It will be absorbed in the parameters that are present in the deterministic part of the utility function. Hence, $\mu_{2}$ is not identified from data.

Stage 2. Given a tax evading strategy 
In order to derive the probabilities for hours supplied when a tax evading strategy is chosen we need some new notation.

Let

$\mathrm{C}_{\mathrm{ijE}, \mathrm{T}}=$ after tax and penalty income when the individual is a tax evader and works $\mathrm{h}_{\mathrm{ij}}=$ $h_{i H}+h_{j E}$ annual hours, where $h_{i H}$ is hours worked in the regular economy and $h_{j E}$ is hours worked in the irregular economy. The subscript $\mathrm{T}$ indicates that the individual's tax evasion is detected and he or she has to pay a fine. The indices $i=1,2,, n$ and $j=1,2,, n$ index hours of work alternatives in the regular and irregular economy, respectively. $\mathrm{C}_{\mathrm{ijE}, \mathrm{NT}}=$ as above, but now tax evasion is not detected.

$\mathrm{W}_{\mathrm{E}}=$ hourly wage rate in the black economy

$R_{j E}=W_{E} h_{j E}$

$\tau=$ the fine that the evader has to pay if detected.

Then

$$
\mathrm{C}_{\mathrm{ij}, \mathrm{E}, \mathrm{T}}=\mathrm{R}_{\mathrm{iH}}+\mathrm{R}_{\mathrm{jE}}+\mathrm{I}-\mathrm{T}\left(\mathrm{R}_{\mathrm{iH}}+\mathrm{R}_{\mathrm{jE}}, \mathrm{I}\right)-\tau\left(\mathrm{R}_{\mathrm{jE}}\right) ; \mathrm{i}, \mathrm{j}=1,2,,, \mathrm{n}
$$

$$
\mathrm{C}_{\mathrm{ij}, \mathrm{E}, \mathrm{NT}}=\mathrm{R}_{\mathrm{iH}}+\mathrm{R}_{\mathrm{jE}}+\mathrm{I}-\mathrm{T}\left(\mathrm{R}_{\mathrm{iH}}, \mathrm{I}\right) ; \mathrm{i}, \mathrm{j}=1,2,, \mathrm{n}
$$

Let $\mathrm{q}$ denote the probability of detection $(1 \geq q \geq 0)$ and let $f(q)$ be a probability weighting function. As mentioned above this probability weighting function may allow for the possibility that individuals give overweight to small probabilities related to undesirable events. The specification used her implies a rank-dependent expected utility model, with the expected utility model as a special case, see Quiggin $(1982,1993) .{ }^{16}$

Thus

\footnotetext{
${ }^{16}$ The functional form implies an inflection point (i.e. where $\left.\mathrm{q}=\mathrm{f}(\mathrm{q})\right)$ at $\mathrm{q}=1 / 2$ for $0<\mathrm{a}<1$. Prelec $(1998$, $\mathrm{p}$. 504-506) discusse the function $\mathrm{w}(\mathrm{p})=\exp \left(-(-\ln \mathrm{p})^{\alpha}\right)$ [in our notation: $\mathrm{f}(\mathrm{q})=\exp \left(-(-\ln \mathrm{q})^{\alpha}\right]$ which generates an inflection point at $p=1 / e=0.37$. Although Prelec argues that empirical data supports an inflection point in the vicinity of 0.37 , we have, because of the reasons in support for the RDEU model, chosen specification (8) in the present study.
} 
(8) $\left\{\begin{array}{l}\mathrm{f}(\mathrm{q})=1-\frac{1}{2}\left[1+(1-\mathrm{q})^{\mathrm{a}}-\mathrm{q}^{\mathrm{a}}\right] ; 1 \geq \mathrm{a} \geq 0 \\ \mathrm{f}(\mathrm{q})=\frac{1}{2} \text { for } \mathrm{a}=0 \\ \mathrm{f}(\mathrm{q})=\mathrm{q} \text { for } \mathrm{a}=1\end{array}\right.$

The weighting function, $\mathrm{f}(\mathrm{q})$, is an inverted s-shaped curve for which the coefficient $a$ determines the curvature. When $a$ approaches 0 , the curve approaches a step function for which $\mathrm{f}(\mathrm{q})=1 / 2$ for $0<\mathrm{q}<1$. When $a$ approaches 1 , the weighting function approaches the diagonal, that is $\mathrm{f}(\mathrm{q})=\mathrm{q}$.

The random utility function, given that the individual follows a tax evading strategy, denoted $\mathrm{U}_{\mathrm{ijE}}$, has two parts. (Remember that subscripts $i$ and $j$ denote the number of hours worked in the regular and in the irregular economy, respectively.) The first part is the deterministic part, which is the expected or rank dependent expected utility related to the lottery of taking part in tax evasion. The second part is the random term, random to the analyst and with the same distribution as the random term in (2). Thus,

(9) $\mathrm{U}_{\mathrm{ijE}}=\mathrm{f}(\mathrm{q}) \mathrm{u}\left(\mathrm{C}_{\mathrm{ij}, \mathrm{E}, \mathrm{T}}, \mathrm{h}_{\mathrm{iH}}+\mathrm{h}_{\mathrm{jE}}, \mathrm{X}\right)+(1-\mathrm{f}(\mathrm{q})) \mathrm{u}\left(\mathrm{C}_{\mathrm{ij}, \mathrm{E}, \mathrm{NT}}, \mathrm{h}_{\mathrm{iH}}+\mathrm{h}_{\mathrm{jE}}, \mathrm{X}\right)+\varepsilon_{\mathrm{ij}} ; \mathrm{i}, \mathrm{j}=1,2,,, \mathrm{n}$

As above, let $\mathrm{S}_{\mathrm{E}}$ be the expected value of the maximum of the expected random utility, that is

$$
\mathrm{S}_{\mathrm{E}}=\mathrm{E}\left[\max _{\mathrm{i}=1,2, n ; \mathrm{j}=1,2, n \mathrm{n}} \mathrm{U}_{\mathrm{ijE}}\right]=\mu_{2} \ln \sum_{\mathrm{k}=1}^{\mathrm{n}} \sum_{\mathrm{r}=1}^{\mathrm{n}} \exp \left(\mathrm{u}_{\mathrm{krE}} / \mu_{2}\right)
$$

where now

(11) $\mathrm{u}_{\mathrm{ijE}}=\mathrm{f}(\mathrm{q}) \mathrm{u}\left(\mathrm{C}_{\mathrm{ijE}, \mathrm{T}}, \mathrm{h}_{\mathrm{iH}}+\mathrm{h}_{\mathrm{jE}}, \mathrm{X}\right)+(1-\mathrm{f}(\mathrm{q})) \mathrm{u}\left(\mathrm{C}_{\mathrm{ijE}, \mathrm{NT}}, \mathrm{h}_{\mathrm{iH}}+\mathrm{h}_{\mathrm{jE}}, \mathrm{X}\right)$

The probability of working $\mathrm{h}_{\mathrm{iH}}$ in the regular economy and $\mathrm{h}_{\mathrm{iE}}$ in the irregular economy, conditional on being a tax evader, is then given by: 


$$
P\left(h_{i H,} h_{j E} \mid E\right)=\frac{\partial S_{E}}{\partial u_{i j E}}=\frac{\exp \left(u_{i j E} / \mu_{2}\right)}{\sum_{k=1}^{n} \sum_{r=1}^{n} \exp \left(u_{r k E} / \mu_{2}\right)} ; i, j=1,2,,, n
$$

Stage 1. Choice of strategy, honest $(H)$ or tax evader (E)

To select strategy in this first stage, the individual compares $\mathrm{S}_{\mathrm{H}}$ and $\mathrm{S}_{\mathrm{E}}$. Because our model is a random utility model we have to derive the probabilities of the two strategies. As outlined in Ben Akiva (1973), Ben-Akiva and Lerman $(1979,1985)$ the probability of choosing an optimal strategy can be evaluated by the expected indirect utility functions $\mathrm{S}_{\mathrm{H}}$ and $\mathrm{S}_{\mathrm{E}}$.

Moreover, we assume that the agent, when deciding on evading taxes or not, pay attention to how socially acceptable the illegal act of evading tax is in society. To represent this in the model we will employ the individuals' perception of this issue as reported in our survey data. It is important to note that we do not introduce the norm variable as the only explanatory variable. We will also assume that the opportunity to evade taxes vary across different types of occupation. In principle we should have modeled the agents' choice of education and choice of sector in the regular economy, together with labor supply and tax evasion, but to do so would have required data beyond what we have access to. The justification for our approach is that the opportunity to evade taxes differs across occupations. For workers say, in the construction sector it is easier not to declare all income to the tax authorities than for those who work in the government sector. To reflect these possible differences in tax evasion opportunities we have introduced two dummy variables, one for those working in the construction sector and one for those working in the government sector.

Our motivation for doing this is that we have the hypothesis that social norms and the work place of the individuals affect the individual's propensity and possibility to evade taxes in addition to economic incentives like taxes and wages.

Let $\mathrm{z}$ be a vector of variables that includes perception of how socially acceptable tax evasion is and industry in which the individual works. Let $\mathrm{g}(\mathrm{z})$ denote a function that will be used to weight the expected indirect utility of tax evasion. Note that there are 
three variables in the $\mathrm{z}$ - vector and hence in the g-function. The empirical specification of the g-function is given below. For more details about weighting choice probabilities with opportunity densities we refer to Creedy and Kalb (2005) and Dagsvik and Strøm (2006).

Let $\mathrm{P}(\mathrm{H})$ denote the probability of pursuing an honest strategy. The probability of choosing the the tax evasion strategy, denoted $\mathrm{P}(\mathrm{E})$, equals $1-\mathrm{P}(\mathrm{H})$.

Then

$$
\left\langle\begin{array}{l}
P(H)=\frac{\exp \left(S_{H} / \mu_{1}\right)}{\exp \left(S_{H} / \mu_{1}\right)+g(z) \exp \left(S_{E} / \mu_{1}\right)} \\
P(E)=1-P(H)
\end{array}\right.
$$

where $\mu_{1}$ is a positive constant. The g-function is attached to the part in the probability which contains the expected indirect utility that follows from the alternatives when the individual is a tax evader. It captures how norms and occupation may affect the choice probabilities of strategies (evasion or not). Following Dagsvik and Strøm (2006) we call this g-function the norm and opportunity density and it follows from eq. (13) that it can be interpreted as weighting the value of the tax evasion strategy in the choice probability.

\section{The unconditional probabilities}

The unconditional probabilities, which relates to the event that we observe, are denoted $\mathrm{P}\left(\mathrm{h}_{\mathrm{iH}}, \mathrm{H}\right)$ and $\mathrm{P}\left(\mathrm{h}_{\mathrm{iH}}, \mathrm{h}_{\mathrm{jE}}, \mathrm{E}\right)$ and are given by

$$
\mathrm{P}\left(\mathrm{h}_{\mathrm{iH}}, \mathrm{H}\right)=\mathrm{P}\left(\mathrm{h}_{\mathrm{iH}} \mid \mathrm{H}\right) \mathrm{P}(\mathrm{H})
$$

and

(15) $P\left(h_{i H}, h_{j E}, E\right)=P\left(h_{i H}, h_{j E} \mid E\right) P(E)$

When $\mu_{2} / \mu_{1}=1$, the nested multinomial logit model (the two stage model outlined above) degenerates to a multinomial logit model, or 
(16) $\mathrm{P}\left(\mathrm{h}_{\mathrm{iH}}, \mathrm{H}\right)=\frac{\exp \left(\mathrm{u}_{\mathrm{iH}} / \mu_{2}\right)}{\sum_{\mathrm{k}=1}^{\mathrm{n}} \exp \left(\mathrm{u}_{\mathrm{kH}} / \mu_{2}\right)+\mathrm{g}(\mathrm{z}) \sum_{\mathrm{k}=1}^{\mathrm{n}} \sum_{\mathrm{r}=1}^{\mathrm{n}} \exp \left(\mathrm{u}_{\mathrm{krE}} / \mu_{2}\right)}$

and

(17) $\mathrm{P}\left(\mathrm{h}_{\mathrm{iH}}, \mathrm{h}_{\mathrm{jE}}, \mathrm{E}\right)=\frac{\mathrm{g}(\mathrm{z}) \exp \left(\mathrm{u}_{\mathrm{ijE}} / \mu_{2}\right)}{\sum_{\mathrm{k}=1}^{\mathrm{n}} \exp \left(\mathrm{u}_{\mathrm{kH}} / \mu_{2}\right)+\mathrm{g}(\mathrm{z}) \sum_{\mathrm{k}=1}^{\mathrm{n}} \sum_{\mathrm{r}=1}^{\mathrm{n}} \exp \left(\mathrm{u}_{\mathrm{krE}} / \mu_{2}\right)}$

The likelihood expression

Let $\mathrm{N}_{\mathrm{H}}$ be the group of individuals in the sample who are observed to follow an honest strategy (they answer no to the question in the questionnaire of whether they have evaded taxes the last twelve months) and let $\mathrm{N}_{\mathrm{E}}$ be the group of tax evaders in the sample. Let subscript $\mathrm{s}$ indicate an individual. The joint a priori probability of what we observe is then given by the likelihood L:

$$
\mathrm{L}=\prod_{\mathrm{s} \in \mathrm{N}_{\mathrm{H}}} \mathrm{P}_{\mathrm{s}}\left(\mathrm{h}_{\mathrm{iH}}, \mathrm{H}\right) \prod_{\mathrm{s} \in \mathrm{N}_{\mathrm{E}}} \mathrm{P}_{\mathrm{s}}\left(\mathrm{h}_{\mathrm{iH}}, \mathrm{h}_{\mathrm{jE}}, \mathrm{E}\right)
$$

The unknown parameters of model are then estimated by maximizing $L$ with respect to these parameters.

\section{Empirical specifications}

Let $\mathrm{v}(\mathrm{C}, \mathrm{h}, \mathrm{X})=\mathrm{u}(\mathrm{C}, \mathrm{h}, \mathrm{X}) / \mu_{2}$. This deterministic part of the utility function is assumed to be a Box-Cox transformation of disposable income and leisure. A justification for this functional form is given in Dagsvik and Strøm (2006).

(19) $\mathrm{v}(\mathrm{C}, \mathrm{h}, \mathrm{X})=\left(\alpha_{0}\right) \frac{(\mathrm{C} / 100000)^{\lambda}-1}{\lambda}+\left(\beta_{0}+\beta_{1} \mathrm{X}_{1}+\beta_{2} \mathrm{X}_{2}\right) \frac{(8760-\mathrm{h})^{\gamma}-1}{\gamma}$, 
where $\mathrm{C}$ is disposable household income. $\mathrm{X}_{1}$ is age (in years) and $\mathrm{X}_{2}$ is dummy, which equals 1 if the individual is a woman and zero otherwise. The coefficient $\mu_{2}$ is absorbed in $\left(\alpha_{0}, \beta_{0}, \beta_{1}, \beta_{2}\right)$. The reason for hours of work in the utility function is that annual leisure in hours, defined as 8760 -h, is assumed to have an impact on individual welfare. In measuring $C$ all details of the step-wise tax-functions are accounted for, see Appendix 2. The fine, if tax evasion is detected, is based on the perceived fines as reported by the respondents. The probability of detection, $\mathrm{q}$, is also based on the individual's perception of detection probabilities as reported by the respondents. The wage rate used to calculate gross earnings equals the ordinary hourly wage rate reported by the respondent in the questionnaire. The same wage rate is used in the regular as well in the irregular economy. It is likely that the wage rate in the irregular part of the economy is less than the wage rate in the regular part, but we do not observe by how much for all participants in the sample. The model requires that all individuals know their potential wage rate in the irregular part of the economy, also those who did not participate. This is a consequence of assuming utility maximizing individuals who compare utilities in order to make their decisions. If we had estimated wage equations for working in the irregular economy, given the survey data, it might have introduced more biases in the model than simply using the reported wage in the regular part of the economy. One would also expect that individual wages in the regular and the irregular economy are strongly correlated.

Hours worked in the regular economy are observed in broad categories and we have used the midpoints $(10,25,37.5,50)$ per week and with 50 hours a week as a maximum. Hours worked in the irregular economy are reported as annual hours, and again in broad categories with midpoints $(10,25,37,75,150,250,600)$ and with 600 as a maximum. In the data set none are observed with zero hours in the regular economy. Hence, we are not taking into account the decision not to participate in the regular labor market. If this should have been done, we would have needed information about nonworking individuals. However, our sample is rather representative for the Norwegian labor market. Unemployment rates are low by international standards and the participation rate among married women is the highest in the world. If we had included the option of not working in the regular economy, without observing anyone doing so, 
there is a risk that we would have included some unobserved elements that could have biased our estimates. Of course, zero hours in the irregular labor market is an option in the model.

Feasible hours deviate somewhat from the model, the main difference being that they differ between the regular and the irregular part of economy. This way of treating feasible hours reflects that working in the irregular economy has the character of being side jobs.

The opportunity and norm density, the g-function, is supposed to be

$$
g(z)=\exp \left(g_{0}+g_{1} z_{1}+g_{2} Z_{2}+g_{3} Z_{3}\right)
$$

The variables appearing in the z-vector are:

$\mathrm{Z}_{1}$ equals 1 if the respondent answers that he or she thinks that people in general accept tax evasion, and it equals zero otherwise, answer to Question 16 in the questionnaire, see Appendix 1.

$\mathrm{Z}_{2}$ equals 1 if the respondent works in the construction sector, otherwise equals zero, $\mathrm{Z}_{3}$ equals 1 if the respondent works in the government sector, otherwise zero.

Our hypotheses are that $z_{1}$ may have a positive impact on the probability of being a tax evader. Moreover, we expect that $z_{2}$ may also have a positive impact on the probability. The reasons why individuals working in the construction sector may have a higher probability of being tax evader are in the first place that they have the skills that often are demanded by households when repairing and building houses, and in the second place this sector is typically organized with many small and also irregular firms. Finally, we expect that $z_{3}$ may have a negative impact on the probability of being a tax evader. In the first place individuals working in the public sector have qualifications that are not in so high demand when it comes to do what irregular workers normally do. In the second place it is not so easy to combine a regular full-time job with irregular jobs. 


\section{Data}

The data we have used are taken from a survey done by a private Norwegian polling institute MMI in October 2003. The recruiting of participants was done by MMI over the telephone, asking the person in the household, above 15 years of age and who most recently celebrated his or her birthday, if he/she wanted to participate in a research study. The recruitment was conducted randomly in the Norwegian population. The individuals who said yes to participate got a questionnaire in anonymous envelopes and were asked to return them by mail. There was no possibility to link the telephone numbers to the returned envelops. Thus anonymity was ensured. Still it could be the case that the respondents underreport their tax evasion activities.

The answer percentage is fairly high, see Table 1 below. $86 \%$ said yes to receive a questionnaire in mail, and $73 \%$ of these individuals filled out the questionnaire and mailed it back, which implies that $63 \%(=0.86 \times 0.73 \times 100)$ of the persons initially contacted ended up participating in the survey. This is a very good response compared to response rates in other surveys, for instance in the consumer expenditure surveys of Statistics Norway.

\begin{tabular}{|l|l|}
\hline \multicolumn{2}{|c|}{$\begin{array}{l}\text { Table 1. Response rates in the } \\
\text { surveys. Norway. } 2003 .\end{array}$} \\
\hline $\begin{array}{l}\text { Asked to participate, } \\
\text { Number of individuals }\end{array}$ & 1742 \\
\hline Agreed to participate, $\%$ & 86 \\
\hline Of which answered, $\%$ & 72 \\
\hline $\begin{array}{l}\text { Returned the } \\
\text { questionnaire, percentage } \\
\text { of asked, } \%\end{array}$ & 63 \\
\hline
\end{tabular}

A relevant question regarding the results is the one of possible systematic bias. A common experience with surveys is that people agreeing to participate might have better knowledge of and a higher interest in the subject in questions than the people refusing to participate. The participants might also have "an agenda" when answering. However, the 2 -staged process of recruiting and filling out of questionnaires allows for some control of the possible bias, see Andresen et al (2005) for more details. In addition to drawing the 
recruiting areas randomly the results have afterwards been weighted as if everyone agreed to participate and filled out the questionnaire.

The survey contains information regarding relevant personal characteristics of the respondents, such as age and employment, economic variables such as income and taxes, and people's engagement in as well as attitudes towards non-reported income activities. The questions asked in the survey are presented in Appendix 1 as well as summary statistics. We note that 11.2 percent of the sample is tax evaders. The evaders work slightly more also in the regular economy than the non-evaders and pay also slightly more in taxes. The evaders are more inclined to think that evasion is socially acceptable, but it is interesting to note that a majority of the non-evaders also is of the same opinion. The evaders' perceptions of fines and detection probabilities are slightly below those of the non-evaders. The survey question that we employ in measuring participation in tax evasion activities is Question no 22: "During the last 12 months, have you received compensation for work that has not been reported or will not be reported to the tax authorities?" Alternatively the answer to question 17 could have been used: "Have you ever been engaged in non-reported income activities?" Given yes to Q22, the correlation between the two answers are 100\%. If Q17 had been used the participation rate had been slightly higher, between 12 and $13 \%$. The reason for using the answer to Q22 is that this answer is related to the values of the economic variables that are reported by the respondents.

\section{Estimates and predictions}

The maximum likelihood estimates of the deterministic part of the utility function, and of the norm and opportunity density, are presented in Table 2 . Note that the dependent variable is two dummies, whether to evade taxes or not (Stage 1 above) and hours of work (Stage 2). Because the utility function is random, the model is expressed in ex-ante choice probabilities of these variables and they enter the likelihood function in equation (18) above. In the table "Consumption" is disposable income in the different states as explained in equations (1), (6) and (7). "Leisure $\mathrm{x}$ age" is the interaction of log leisure 
and age and "Leisure $\mathrm{x}$ female" is the interaction between log leisure and a dummy equal to1 if the respondent is a woman.

It turned out that the best fit was with the deterministic part being a log-linear function of leisure, rather than a Box-Cox transformation of leisure. Note that when the exponent in the Box-Cox transformation of leisure goes to zero the functional form becomes log-linear in leisure. In the estimation $\mu_{2} / \mu_{1}$ was not significantly different from 1. We have thus estimated a multinomial logit model.

The estimates show that the marginal utility of disposable income is positive, but declining $(\lambda<1)$. Marginal utility of leisure (or rather of not working outside home) is higher among women than among men, which cet.par. reduce the incentives among women to do illicit work.

The graph of the estimated weighting function,

$$
f(q)=1-\frac{1}{2}\left(1+(1-q)^{0.3567}\right)-q^{0.3567}
$$

is presented in Figure 1.

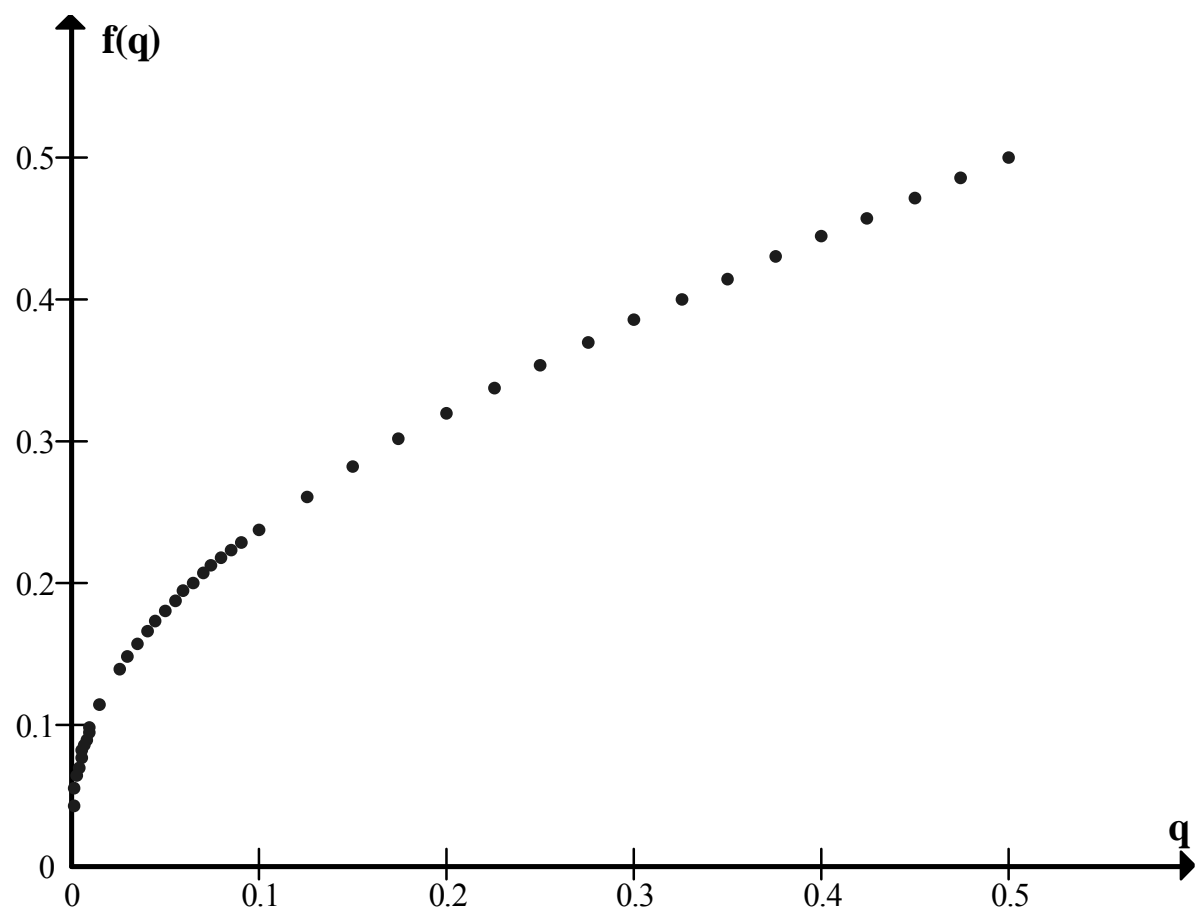

Figure 1.The estimated weighting function 
Our hypothesis that the agents are overweighting detection probabilities is corroborated. Whereas the summary statistics show that the perceived detection probability is 0.10 for non-evaders and 0.07 for evaders, the estimate $(\mathrm{a}=0.3567)$ implies an average of the weighted probability of about 0.23 . If the objective probability of being caught is about the same as in other countries (cf footnote 5 above), say 0.03 , the perceived detection probability turns out to be about three times as high. With these estimates the puzzle of over-compliance is not that much of a puzzle. From Table 2 we note that the coefficient $a$ is at the border of not being significant different from 0 , which means that the perceived detection probabilities are not significant different from 0.5 . The latter means that the individuals toss a coin when calculating the chances of being detected, which of course is a very high overweighting of detection probabilities. The expected utility model, EU, is a special case of our model. This occurs when a=1, which implies that $f(q)=q$, see equation (8). Thus, the EU model is strongly rejected.

The estimate of $g_{1}$ indicates that the more the agents think that tax evasion is accepted in the society, the more they evade. To work in the construction sector increases the probabilities of working in the irregular economy. 


\begin{tabular}{|l|l|l|l|}
\hline \multicolumn{3}{|l|}{ Table 2. Estimates of the utility function and the norm and opportunity density } \\
\hline Parameters & Variables & Estimates & t-values \\
\hline$\alpha$ & $\begin{array}{l}\text { Consumption, } \\
\text { constant }\end{array}$ & 3.0176 & 7.9 \\
\hline$\lambda$ & $\begin{array}{l}\text { Consumption, } \\
\text { exponent }\end{array}$ & 0.7196 & 9.4 \\
\hline$\beta_{0}$ & Leisure, constant & 10.5402 & 3.5 \\
\hline$\beta_{1}$ & Leisure x age & 0.0261 & 0.5 \\
\hline$\beta_{2}$ & Leisure x female & 3.2374 & 2.9 \\
\hline $\mathrm{a}$ & Detection prob. & 0.3567 & 1.8 \\
\hline $\mathrm{g}_{0}$ & Opportunity, & -4.8401 & -16.8 \\
\hline $\mathrm{g}_{1}$ & constant & & 3.3 \\
\hline $\mathrm{g}_{2}$ & Norm & 0.9709 & 3.2 \\
\hline $\mathrm{g}_{3}$ & Construction sector & 1.2029 & -0.8 \\
\hline No of observations & Govt. sector & -0.6427 & \\
\hline Log-likelihood & & -1068.74 & \\
\hline McFaddens rho & & 0.537 & \\
\hline & & & \\
\hline
\end{tabular}

Goodness of fit is defined as 1 minus the log-likelihood related to the estimates, relative to the log-likelihood when all alternatives have an equal chance to be chosen ("McFaddens rho"). Here McFaddens rho equals 0.537, which means that the empirical model explains data $53.7 \%$ better than if all choices had been made at pure random. Thus the economic incentives, norms and opportunities introduced in the model matter for the decisions made by the respondents.

In order to explain further how the model fits data we have predicted how well it predicts hours of work and tax revenues. This is an important test on the model since the main outcome of the model is labor supply. To predict labor supply outcomes and taxes paid we need the following new notation. 


$$
\begin{aligned}
&\left(L_{H} \mid H\right)=52 \sum_{i=1}^{5} P\left(h_{i H} \mid H\right) h_{i H} \\
&\left(L_{H} \mid E\right)=52 \sum_{i=1}^{5} \sum_{i=1}^{8} P\left(h_{i H}, h_{j E} \mid E\right) h_{i H} \\
&(21) \quad\left(L_{E} \mid E\right)=\sum_{i=1}^{5} \sum_{i=1}^{8} P\left(h_{i H}, h_{j E} \mid E\right) h_{j E} \\
& L_{H}=P(H)\left(L_{H} \mid H\right)+P(E)\left(L_{H} \mid E\right) \\
& L_{E}=P(E)\left(L_{E} \mid E\right)
\end{aligned}
$$

Here

$\left(\mathrm{L}_{\mathrm{H}} \mid \mathrm{H}\right)$ :expected annual hours of work in the regular economy, given honest

$\left(\mathrm{L}_{\mathrm{H}} \mid \mathrm{E}\right)$ : expected annual hours of work in the regular economy, given evader

$\left(\mathrm{L}_{\mathrm{E}} \mid \mathrm{E}\right)$ : expected annual hours of work in the irregular economy, given evader

$\mathrm{L}_{\mathrm{H}}$ : expected annual hours of work in the regular economy

$\mathrm{L}_{\mathrm{E}}$ : expected annual hours of work in the irregular economy

52 are the number of weeks per year.

In addition we report the tax revenues in the different cases. $T_{H}$ is the expected amount of taxes paid by the non-evaders, while $\mathrm{T}_{\mathrm{H} \mid \mathrm{E}}$ is the expected amount of taxes paid the evaders. $\mathrm{T}$ is the expected amount of taxes paid in the total population, which, of course, lies between the two others.

Predictions and observed outcomes are given in Table 3. To predict the outcomes of the model we first predict the outcomes for each individual and then we aggregate. We observe that the model predicts the outcomes rather precisely. The model gives a rather remarkable good prediction of hours supplied in the regular part of the economy, in particular among the tax evaders. There is one exception: Hours worked in the irregular economy. A possible source of too high predictions of unregistered labor supply is that the observed hours of unregistered work may not be the hours supplied, since not all individuals are free to work unregistered as many hours as they want. For example, many of the respondents are employees who work in firms where it not so easy to combine irregular work with their main full time occupation, even if they had preferred to do so. Examples are individuals working in the government sector, in hospitals, in energy companies and supermarkets. An important aspect of structural models that deals with labor supply and taxation, here also with tax evaders included, is how well it predicts 
taxes paid. From Table 3 we observe that although the model predicts a somewhat lower amount paid by the tax evaders than observed, the prediction of taxes paid in the whole population is rather accurate.

Table 3. Observed and predicted outcomes

\begin{tabular}{|c|c|c|}
\hline & Observered & Predicted \\
\hline Shares of non-evaders $\mathrm{P}(\mathrm{H})$ & 0.88782 & 0.88816 \\
\hline Shares of evaders, $\mathrm{P}(\mathrm{E})$ & 0.11218 & 0.11184 \\
\hline $\begin{array}{l}\text { Expected annual hours in the } \\
\text { regular economy, given honest } \\
\left(\mathrm{L}_{\mathrm{H}} \mid \mathrm{H}\right)\end{array}$ & 1733 & 1880 \\
\hline $\begin{array}{l}\text { Expected annual hours in the } \\
\text { regular economy, given dishonest } \\
\left(\mathrm{L}_{\mathrm{H}} \mid \mathrm{E}\right)\end{array}$ & 1768 & 1730 \\
\hline $\begin{array}{l}\text { Expected annual hours in the } \\
\text { irregular economy, given } \\
\text { dishonest }\left(\mathrm{L}_{\mathrm{E}} \mid \mathrm{E}\right)\end{array}$ & 79 & 300 \\
\hline $\begin{array}{l}\text { Expected annual hours in the } \\
\text { regular economy } \mathrm{L}_{\mathrm{H}}\end{array}$ & 1736 & 1865 \\
\hline $\begin{array}{l}\text { Expected annual hours in the } \\
\text { irregular economy } \mathrm{L}_{\mathrm{E}}\end{array}$ & 9 & 34 \\
\hline $\begin{array}{l}\text { Annual taxes paid, given honest, } \\
\mathrm{T}_{\mathrm{H}}, \mathrm{NOK}^{*}\end{array}$ & 82750 & 86839 \\
\hline $\begin{array}{l}\text { Annual taxes paid, given } \\
\text { dishonest, } \mathrm{T}_{\mathrm{H} \mid \mathrm{E}}, \mathrm{NOK}\end{array}$ & 83041 & 75403 \\
\hline Annual taxes paid, T, NOK & 82782 & 85642 \\
\hline
\end{tabular}

\section{Labor supply elasticities}

In Table 4 we report the elasticity of labor supply aggregates (or weighted individual elasticities) with respect to wages rates. In the model feasible hours of work are 7 
alternative hours per week in the regular economy and 7 alternatives per year in the irregular economy. Because preferences are random the choice of hours are represented through choice probabilities. Expected hours worked, as shown in eq. (21), is then the weighted sum of the feasible hours of work, weighted with the estimated probabilities. When wage rates change, these probabilities change. The probabilities depend on disposable income, as outlined in the model. This is the basis for calculating elasticities.

The within-sector elasticities are moderate, but the between-sector elasticities are sizable. We observe that an overall wage increase of 1 percent will increase supply of regular hours by 0.23 percent and reduce the supply of irregular hours by 0.41 percent. Thus we should expect that the size of the shadow economy is declining when real wages are increasing as they normally are during economic growth periods. This also implies that if real wages are declining say, due to a recession, we should expect that the shadow economy is growing. The impact of wages on choice probabilities are in part substitution effects and in part income effects.

\section{Table 4. Labor supply elasticities}

\begin{tabular}{l|c|c|c|c}
\hline \multirow{2}{*}{\multicolumn{1}{c|}{ Variables }} & \multirow{2}{*}{$\begin{array}{c}\text { Intial } \\
\text { predicted } \\
\text { outcome }\end{array}$} & \multicolumn{2}{c}{ Elasticities wrt to wage levels } \\
\cline { 3 - 5 } & & $\begin{array}{c}\text { In regular } \\
\text { economy }\end{array}$ & $\begin{array}{c}\text { In } \\
\text { irregular } \\
\text { economy }\end{array}$ & Overall \\
& & & & \\
\hline Probability of... & 0.89 & 0.11 & -0.09 & 0.03 \\
$\ldots$..honest strategy & 0.11 & -0.91 & 0.70 & -0.30 \\
\hline .evasion strategy & & & & \\
\hline $\begin{array}{l}\text { Annual expected hours: } \\
\text { Regular hours, given honest }\end{array}$ & 1880 & 0.25 & 0 & 0.25 \\
Regular hours, given evasion & 1730 & 0.23 & -0.19 & 0.06 \\
Irregular, given evasion & 300 & -0.72 & 0.60 & -0.13 \\
\hline $\begin{array}{l}\text { Annual hours: } \\
\text { Regular }\end{array}$ & 1865 & 0.26 & -0.03 & 0.23 \\
Irregular & 34 & -1.57 & 1.36 & -0.41 \\
\hline
\end{tabular}




\section{Conclusion}

A labour supply model in which the individuals have the option to evade taxes by working in the irregular economy is estimated on Norwegian survey data from October 2003. A growing number of studies indicate that people tend to overweigh low probabilities of losses. The possibility of being sanctioned for tax evasion might be an example of such losses, and we find that the hypothesis that people are overweighting subjective probabilities of being detected is corroborated. Tax payers' belief about social norms also has an effect on the tax evasion decision.

But economic incentives like wages and taxes are also found to play a role in explaining behaviour. The model can thus be used in policy simulations. An example is changes in tax rates and to find how these changes can reduce tax evasion and stimulate labor supply in the regular part of the economy.

The model predicts hours worked rather precisely both among the tax evaders and the non-evaders. The labor supply elasticities show that an overall wage increase in the society may shift labor supply away from the irregular economy and towards the regular economy. This also means that during recessions when real wages are declining one should expect that tax evading activities will increase.

The reported participation in the shadow economy the last 12 months gives a participation rate of around $11 \%$. This together with irregular work being typically side jobs implies that the shadow economy in percent of GDP is substantially below estimates reported by Schneider (2007). For 2002-2003 he estimates the size of the Norwegian shadow economy in percent of GDP to 18.4 percent. This is a rather high estimate and puts the shadow economy above the oil and gas sector in Norway that year. His estimate is based on macroeconomic variables and in particular on money stocks and flows. The estimate also includes more shadow activities than otherwise legal work.

Our approach is based on microdata collected in surveys and it could well be that our estimates of tax evading activities is somewhat on the low side, while it seems that Schneider's estimates is on the high side. The purpose of our approach, however, is not to 
give a precise estimate of the shadow economy in percent of GDP, but to investigate labor supply behaviour when tax evasion is an option.

It is however true that the survey data implies that tax evading activities in Norway are minor. Findings that support this implication is given in Andresen et al (2005), where it is shown that the participation rate in the shadow economy in Norway has declined monotonically from 20 percent in 1980 to 11 percent in 2003 . There is one exception. In 1988-1989 Norway went through a recession with increased unemployment and reductions in real wages. In 1989 the participation rate in shadow activities increased.

The reasons for the decline in shadow activities over the last 20-30 years are changes in the tax structure towards less progressive taxes, increase in real wages and income, more regular jobs and a substantial increase in the number of people working in the public sector. Moreover, since 1980 female participation in regular jobs outside home has increased to an extent that Norway now is number 1 in the world with respect to female labor market participation. Contini (1981) mentions higher female labor market participation as an important reason for less participation in the shadow economy among women.

These reasons for the gradually decline in tax evading activities over the last 2030 years accords well with the findings in this paper. 


\section{References}

Allais. Maurice (1953): La Psychologie de l'Homme Rationnel devant le risqué. La Théorie et l'Expérience. Journal de la Société de Statistique de Paris, 47-73 Allingham, Michael G. and Agnar Sandmo (1972): Income Tax Evasion: A Theoretical Analysis. Journal of Public Economics, 1, 323-338.

Anderson, Simon, Andre de Palma and Jacques-Francois Thisse (1992): Discrete Choice Theory of Product Differentiation, Cambridge, MA: MIT press

Andreoni, James, Brian Erard and Jonathan Feinstein (1998): Tax Compliance. Journal of Economic Literature, 36, 818-860.

Andresen, Kari Due, Tone Ognedal and Steinar Strøm (2005):“The shadow economy in Norway 1980-2003: Some empirical evidences from voluntary sample surveys", in C. Bajada and F. Schneider (eds): "Size, causes and consequences of the underground economy”Ashgate Publishing Ltd, Aldershot, England and Burlington, USA, 139-156

Arcand, Jean-Louis and Grégoire Rota Grazioai (2005): Tax Compliance and Rank Dependent Expected Utility. The Geneva Risk and Insurance Review, 30 (1), 5769.

Ben-Akiva, Moshe (1973): Structure of Passenger Travel Demand Models. Ph.D. Dissertation. Department of Civil Engineering, MIT, Cambridge, Mass.

Ben-Akiva, M. and Steven R. Lerman(1979): Disaggregate Travel and Mobility Choice Models and Measures of Accessibility. In D. Henscher and P. Stopher (eds): Behavioral Travel Modelling. Croom Helm, London.

Ben-Akiva, Moshe and Steven R. Lerman (1985): Discrete Choice Analysis. MIT Press: Cambridge, MA.

Bernasconi, M. (1998): Tax Evasion and Orders of Risk Aversion. Journal of Public Economics, 67, 123-134.

Birnbaum, Michael H., Jamie N. Patton, and Melissa K. Lott (1999): Evidence Against Rank-Dependent Utility Theories: Tests of Cumulative Independence, Interval 
Independence, Stochastic Dominance, and Transitivity. Organizational Behavior and Human Decision Processes, 77 (1), 44-83.

Camerer, C. F. and T. H. Ho (1994): Violations of the Betweenness Axiom and Nonlinearity in Probability. Journal of Risk and Uncertainty, 8, 167-196.

Camerer, C. (1995): Individual Decision Making. In J. H. Kagel and A. E. Roth (eds.), The Handbook of Experimental Economics, Princeton, NJ: Princeton Univ. Pr., 587-703.

Cho, Younghee, R. Duncan Luce, and Detlof von Winterfeldt (1994): Tests of Assumptions About the Joint Receipt of Gambles in Rank- and Sign-Dependent Utility Theory. Journal of Experimental Psychology: Human Perception and performance, 20, 931-943.

Chung, Ngar-Kok, Detlof von Winterfeldt, and R. Duncan Luce (1994): An Experimental Test of Event Communativity in Decision Making Under Uncertainty. Psychological Science, 5, 394-400.

Contini, B. (1981): "Labor Market Segmentation and the Development of the Parallel Economy- the Italian Experience", Oxford Economic Papers, 33:4, pp 401-412

Creedy, John and Guyonne Kalb (2005): Discrete Hours Labour Supply Modelling; Specification, Estimation and Simulation. Journal of Economic Surveys, 19(5), $697-734$

Dagsvik, John K. and Steinar Strøm (2006); Sectoral Labor Supply, Choice Restrictions and Functional Form. Journal of Applied Econometrics, 21, 803-826.

Dhami, Sanjit and Ali al-Nowaihi (2007): Why Do People Pay Taxes? Prospect Theory Versus Expected Utility Theory. Journal of Economic Behavior and Organization, 64 (1), 171-192.

Eide, Erling (2003): Optimal Provision of Public Goods with Rank Dependent Expected Utility. Public Finance/Finances Publiques, 53, 296-311.

Elster, J. (1989): The cement of society. A study of social order, Cambridge University Press, Cambridge

Erhard, B and J. S. Feinstein (1994): The Role of Moral Sentiments and Audit Perceptions in Tax Compliance. Public Finance, 49, 70-89. 
Falk, Armin and Ernst Fehr (2002): Psychological foundations of incentives. European Economic Review, 46, 687-724.

Feinstein, J. S. (1998): Tax Compliance, in: Peter Newman (ed.), The New Palgrave Dictionary of Economics and the Law, 3, 574-579.

Feinstein, J. S. (1999): Approaches for Estimating Noncompliance: Examples from Federal Taxation in the United States. The Economic Journal, 109, F360-F369.

Frey, Bruno S. and Benno Torgler (2007): Tax morale and conditional cooperation. Journal of Comparative Economics, 35, 136-159.

Fox, C and A Tversky (1998): A Belief-based Account of Decision under Uncertainty. Management Science, 44, 879-895.

Gilboa, I. (1987): Expected Utility with Purely Subjective Non-additive Probabilities. Journal of Mathematical Economics, 16, pp. 65-88.

Gonzales, Richard and George Wu (1999): On the Shape of the Probability Weighting Function. Cognitive Psychology, 38, 129-166.

Gordon, J. P. F. (1989): Individual morality and reputation costs as deterrents to tax evasion, European Economic Review, 33, 797-805.

Grasmick, H. G. and W. J. Scott (1982): Tax Evasion and Mechanisms of Social Control: A Comparison with Grand and Petty Theft. Journal of Economic Psychology, 2, 213-230.

Hasseldine, J. and S. E. Kaplan (1992): The effect of different sanction communications on hypothetical taxpayer compliance: Policy implications from New Zeeland. Public Finance, 47, 45-70.

Henrich, Joseph (2004): Cultural group selection, coevolutionary processes and largescale cooperation. Journal of Economic Behavior and Organization, 53, 3-35.

Hey, J. D. and C. Orme (1994): Investigating Generalizations of Expected Utility Theory using Experimental Data. Econometrica, 62, 1291-1326.

Kahneman; Daniel and Amos Tversky (1979): Prospect Theory: An Analysis of Decision under Risk. Econometrica, 47, 263-291.

Kelman, H. C. (1958): Compliance, Identification, and Internalization: Three Processes of Attitude Change. Journal of Conflict Resolution, 2, 51-60 
Kilka, Michael and Martin Weber (2001): What Determines the Shape of the Probability Weighting Function Under Uncertainty? Management Science, 47, 1712-1726. Lacroix, Guy. and Bernard Fortin (1992): Utility-based estimation of labour supply functions in the regular and the irregular sectors, Economic Journal, 102, 14071422.

Lemieux, Thomas, Bernard Fortin and Pierre Frechette (1994): The effect of taxes on labor supply in the underground economy, American Economic Review, 84, 231254.

Lopes, Lola L. (1987): Between Hope and Fear: The Psychology of Risk. Advances in Experimental Social Psychology, 20, 255-295.

Lopes, L. (1990): Re-modeling risk aversion: A comparison of Bernoullian and rank dependent value approaches. In G.M. v. Furstenberg (eds.), Acting under uncertainty, 267-299. Boston: Kluwer.

Marchese, Carla and Fabio Privileggi, (1997): Taxpayer's Attitudes toward Risk and Amnesty Participation: Economic Analysis and Evidence for the Italian Case. PublicFinance/Finances Publiques, 52, 394-410.

Myles, Gareth D, and Robin A. Naylor (1996): A model of tax evasion with group conformity and social customs. European Journal of Political Economy, 12, 4966.

Prelec, Drazen (1998): The Probability Weighting Function. Econometrica, 66 (3), $497-$ 527.

Quiggin, John (1982): A Theory of Anticipated Utility. Journal of Economic Behaviour and Organisation, 3, 323-343.

Quiggin, John (1993): Generalized Expected Utility Theory: The Rank Dependent Model. Academic Publishers, Boston/Dordrecht/London.

Rabin, Matthew (1998): Psychology and Economics. Journal of Economic Litterature, $36,11-46$.

Reckers, P. M., D. L. Sanders, and S. J. Roark (1994): The influence of ethical attitudes on taxpayer compliance. National Tax Journal, 47, 825-836. 
Schmeidler, D. (1989): “Subjective Probability and Expected Utility without Additivity”, Econometrica, 57, pp. 571-87.

Schneider, Friedrich (2007): The Size of the Shadow Economies of 145 Countries all over the World: First Results over the Period 1999-2003, Journal of Population Economics, 20(3), 495-526

Schneider, Friedrich and Dominik H. Enste (2000): Shadow Economies: Sizes, Causes and Consequences, Journal of Economic Literature, 38, 77-114

Schwartz, Richard and Sonya Orleans (1967): On Legal Sanctions. The University of Chicago Law Review, 34, 274-300.

Segal, Uzi (1987): Some Remarks on Quiggin's Anticipated Utility, Journal of Economic Behavior and Organization, 8, 145-154.

Slemrod, J. (1992): Why People Pay Taxes: Tax Compliance and Enforcement. Ann Arbor, MI, University of Michigan Press.

Starmer, Chris (2002): Developments in Non-Expected Utility Theory: The Hunt for a Descriptive Theory of Choice under Risk. Journal of Economic Literature, XXXVIII (June), 332-382.

Tversky, A. and D. Kahneman (1992): Advances in Prospect Theory: Cumulative Representation of Uncertainty. Journal of Risk and Uncertainty, 5, 297-323.

Viscusi W. Kip (1992): Fatal Tradeoffs: Public and Private Responsibilites for Risk. New York and Oxford, Oxford University Press.

Wakker, Peter P., Ido Erev, and Elke U. Weber (1994): “Comonotonic Independence: The Critical Test between Classical and Rank-Dependent Utility Theories. Journal of Risk and Uncertainty, 9, 195-230.

Weber, Elke U. and Britt Kirsner (1997): Reasons for Rank-Dependent Utility Evaluation, Journal of Risk and Uncertainty, 14, 41-61.

Wenzel, Michael (2004): The Social Side of Sanctions: Personal and Social Norms as Moderators of Deterrence. Law and Human Behavior, 28(5), 547-567.

Wu, G. and R. Gonzales (1996): Curvature of the Probability Weighting Function. Management Science, 42, 1676-1690.

Wu, G. and R. Gonzales (1999): Nonlinear Decision Weights in Choice under Uncertainty. Management Science, 45, 74-85. 
Yaari, Menahem E. (1987): The Dual Theory of Choice under Risk, Econometrica, 55, 95-115.

Yitzhaki, Shlomo (1974): A Note on Income Tax Evasion: A Theoretical Analysis. Journal of Public Economics, 3(2), 201-202. 


\section{Appendix 1. The questionnaire.}

\section{Questions asked in the questionnaire}

The respondents were asked to cross out answer-alternatives that vary across the questions. These alternatives are not shown here, but are available upon request.

Q.1. Gender

Q.2. Age

Q.3. Number of children living in the house

Q.4. Marital status

Q.5. Does your spouse have income generating work, and if so, how many hours?

Q.6. Education in years

Q.7. Occupational status (wage worker, self-employed, unemployed, retired, etc)

Q.8. Hours of work last week in the regular economy

Q.9. Hourly wage rate in main occupation

Q.10. Annual, net income (after tax) in main occupation

Q.11. Annual gross income in main occupation

Q.12 Occupation by industry

Q.13. Do you receive other income than wage income such as social security

benefits/unemployment benefits/capital income?

Q.14. What is your tax rate for overtime work, the marginal tax rate in percent?

Q.15 How much tax do you pay in percent of your total annual gross income?

Q.16. What do you think is the attitude among people with respect to receive payment for work that is not reported to the tax authorities? Do you think it is

accepted/accepted to some extent/not accepted/don't know

Q.17. Have you ever been engaged in non-reported income activities?

Q.18. If so, what kind of activities was it?

Q.19. If you had the opportunity to receive income without having to report it to the tax authorities, would you then accepted such income?

Q.20. If you don't report income to the tax authorities, how large do you think the 
chance (percent) is that you would be caught?

Q.21. If you do not report income to the tax authorities, say NOK 20000 , and you are caught; you have to pay a penalty tax in addition to the regular tax on the nonreported income. How large do you think this penalty tax rate is (percent)?

Q.22. During the last 12 months, have you received compensation for work that has not been reported or will not be reported to the tax authorities?

Q.23. Approximately how many hours of non-reported work have you done during the last 12 months?

Q.24. At the last tax declaration; what was the total annual income from work and capital income that you did not report? 
Table A, 1. Summary statistics: The whole sample, Norway 2003

\begin{tabular}{|c|c|c|c|c|}
\hline \multicolumn{3}{|c|}{ Number of observations } & \multicolumn{2}{|l|}{626} \\
\hline \multicolumn{3}{|c|}{ Number of non-evaders } & \multicolumn{2}{|l|}{556} \\
\hline \multicolumn{3}{|l|}{ Number of evaders } & \multicolumn{2}{|l|}{70} \\
\hline \multicolumn{3}{|c|}{ Share of women in the sample, percent } & \multicolumn{2}{|l|}{52} \\
\hline \multicolumn{3}{|c|}{$\begin{array}{l}\text { Percentage that thinks that tax evasion is socially } \\
\text { acceptable }\end{array}$} & \multicolumn{2}{|l|}{53} \\
\hline & Average & StD & Min & Max \\
\hline Age, years & 41 & 10 & 20 & 60 \\
\hline Hourly wage, NOK* & 151 & 38 & 85 & 230 \\
\hline $\begin{array}{l}\text { Gross annual wage } \\
\text { income, NOK }\end{array}$ & 294581 & 119268 & 48100 & 598000 \\
\hline $\begin{array}{l}\text { Hours per week } \\
\text { worked in the } \\
\text { regular economy }\end{array}$ & 37 & 10 & 10 & 50 \\
\hline $\begin{array}{l}\text { Annual tax paid, } \\
\text { NOK }\end{array}$ & 82782 & 53069 & 5694 & 231146 \\
\hline $\begin{array}{l}\text { Perceived fine, } \\
\text { percent }\end{array}$ & 19.5 & 13.6 & 0.7 & 37 \\
\hline $\begin{array}{l}\text { Perceived detection } \\
\text { probability }\end{array}$ & 0.10 & 0.06 & 0.025 & 0.25 \\
\hline
\end{tabular}

* September 20: 1Euro=NOK 7.9 
Table A. 2. Summary statistics: Non-evaders, Norway 2003. Means

\begin{tabular}{l|l}
\hline Age, years & 41 \\
Percentage women & 54 \\
\hline Weekly hours in the regular economy & 36 \\
Hourly wage, NOK & 151 \\
Gross wage income, NOK & 293162 \\
Annual tax, NOK & 82750 \\
\hline Perceived fine, percent & 19.6 \\
Perceived detection probability & 0.10 \\
\hline Percentage that thinks that tax evasion is & 51 \\
socially acceptable & \\
\hline
\end{tabular}

Table A. 3. Summary statistics: Evaders, Norway 2003. Means.

\begin{tabular}{l|l}
\hline Age, years & 39 \\
Percentage women & 31 \\
\hline Weekly hours in the regular economy & 39 \\
Annual hours in the irregular economy & 80 \\
Hourly wage, NOK & 151 \\
Annual gross income from regular and & 307221 \\
irregular work, NOK & \\
Annual tax, NOK & 83041 \\
\hline Perceived fine, percent & 18.6 \\
Perceived detection probability & 0.07 \\
\hline Percentage that thinks that tax evasion is & 74 \\
socially acceptable & \\
\hline
\end{tabular}




\section{Appendix 2.Tax function, Norway 2003}

\begin{tabular}{|l|l|}
\hline Income $\mathrm{Y}, \mathrm{NOK}$ & Tax, NOK \\
\hline $0-23400$ & 0 \\
\hline $23400-33430$ & $0.25 \mathrm{Y}-5750$ \\
\hline $33430-63400$ & $0.078 \mathrm{Y}$ \\
\hline $63400-132500$ & $0.358 \mathrm{Y}-17752$ \\
\hline $132500-190417$ & $0.2908 \mathrm{Y}-8848$ \\
\hline $190417-340700$ & $0.358 \mathrm{Y}-21664$ \\
\hline $340700-872000$ & $0.493 \mathrm{Y}-67639$ \\
\hline $872000-$ & $0.553 \mathrm{Y}-49959$ \\
\hline
\end{tabular}




\section{CESifo Working Paper Series}

for full list see www.cesifo-group.org/wp

(address: Poschingerstr. 5, 81679 Munich, Germany, office@cesifo.de)

3148 Ilja Neustadt and Peter Zweifel, Is the Welfare State Sustainable? Experimental Evidence on Citizens’ Preferences for Redistribution, August 2010

3149 Marcus Dittrich and Andreas Knabe, Wage and Employment Effects of Non-Binding Minimum Wages, August 2010

3150 Shutao Cao, Enchuan Shao and Pedro Silos, Fixed-Term and Permanent Employment Contracts: Theory and Evidence, August 2010

3151 Ludger Woessmann, Cross-Country Evidence on Teacher Performance Pay, August 2010

3152 Lorenzo C. G. Pozzi, Casper G. de Vries and Jorn Zenhorst, World Equity Premium Based Risk Aversion Estimates, August 2010

3153 Volker Grossmann, Thomas M. Steger and Timo Trimborn, Dynamically Optimal R\&D Subsidization, August 2010

3154 Alexander Haupt, Tim Krieger and Thomas Lange, A Note on Brain Gain and Brain Drain: Permanent Migration and Education Policy, August 2010

3155 António Afonso and Christophe Rault, Long-run Determinants of Sovereign Yields, August 2010

3156 Franziska Tausch, Jan Potters and Arno Riedl, Preferences for Redistribution and Pensions. What can we Learn from Experiments?, August 2010

3157 Martin Kolmar and Andreas Wagener, Inefficient Group Organization as Optimal Adaption to Dominant Environments, August 2010

3158 Kai Carstensen, Klaus Wohlrabe and Christina Ziegler, Predictive Ability of Business Cycle Indicators under Test: A Case Study for the Euro Area Industrial Production, August 2010

3159 Horst Rottmann and Timo Wollmershäuser, A Micro Data Approach to the Identification of Credit Crunches, August 2010

3160 Philip E. Graves, Appropriate Fiscal Policy over the Business Cycle: Proper Stimulus Policies Can Work, August 2010

3161 Michael Binder and Marcel Bluhm, On the Conditional Effects of IMF Program Participation on Output Growth, August 2010

3162 Michael Binder, Qianying Chen, and Xuan Zhang, On the Effects of Monetary Policy Shocks on Exchange Rates, August 2010 
3163 Felix J. Bierbrauer, On the Optimality of Optimal Income Taxation, August 2010

3164 Nikolaus Wolf, Europe’s Great Depression - Coordination Failure after the First World War, September 2010

3165 Dan Kovenock and Brian Roberson, Conflicts with Multiple Battlefields, September 2010

3166 Jean-Pierre Ponssard and Catherine Thomas, Capacity Investment under Demand Uncertainty. An Empirical Study of the US Cement Industry, 1994-2006, September 2010

3167 Jørgen Juel Andersen, Jon H. Fiva and Gisle James Natvik, Voting when the Stakes are High, September 2010

3168 Michael Hoel, Is there a Green Paradox?, September 2010

3169 Scott Alan Carson, Nineteenth Century US African-American and White Female Statures: Insight from US Prison Records, September 2010

3170 Gil S. Epstein, Yosef Mealem and Shmuel Nitzan, Political Culture and Discrimination in Contests, September 2010

3171 Sara Fisher Ellison, Jeffrey Greenbaum and Wallace P. Mullin, Diversity, Social Goods Provision, and Performance in the Firm, September 2010

3172 Silvia Dominguez-Martinez, Randolph Sloof and Ferdinand von Siemens, Monitoring your Friends, not your Foes: Strategic Ignorance and the Delegation of Real Authority, September 2010

3173 Marcus Dittrich and Beate Schirwitz, Union Membership and Employment Dynamics: A Note, September 2010

3174 Francesco Daveri, Paolo Manasse and Danila Serra, The Twin Effects of Globalization - Evidence from a Sample of Indian Manufacturing Firms, September 2010

3175 Florian Blöchl, Fabian J. Theis, Fernando Vega-Redondo and Eric O’N. Fisher, Which Sectors of a Modern Economy are most Central?, September 2010

3176 Dag Morten Dalen, Marilena Locatelli and Steinar Strøm, Longitudinal Analysis of Generic Substitution, September 2010

3177 Armin Falk, Stephan Meier and Christian Zehnder, Did we Overestimate the Role of Social Preferences? The Case of Self-Selected Student Samples, September 2010

3178 Christian Fahrholz and Cezary Wójcik, The Bail-Out! Positive Political Economics of Greek-type Crises in the EMU, September 2010

3179 Klaus Abberger and Wolfgang Nierhaus, The Ifo Business Cycle Clock: Circular Correlation with the Real GDP, September 2010 
3180 Walter Krämer and Gerhard Arminger, “True Believers” or Numerical Terrorism at the Nuclear Power Plant, September 2010

3181 Bernard M.S. Van Praag, Dmitri Romanov and Ada Ferrer-i-Carbonell, Happiness and Financial Satisfaction in Israel. Effects of Religiosity, Ethnicity, and War, September 2010

3182 Dimitrios Koumparoulis and Paul De Grauwe, Public Capital, Employment and Productivity: An Empirical Investigation for Greece, September 2010

3183 John Whalley and Tanmaya Shekhar, The Rapidly Deepening India-China Economic Relationship, September 2010

3184 Andreas Schäfer and Thomas Steger, History, Expectations, and Public Policy: Economic Development in Eastern Germany, September 2010

3185 Thomas Eichner and Marco Runkel, Subsidizing Renewable Energy under Capital Mobility, September 2010

3186 Konstantinos Angelopoulos and James Malley, Fear of Model Misspecification and the Robustness Premium, September 2010

3187 Philip E. Graves, A Note on the Design of Experiments Involving Public Goods, September 2010

3188 Glenn Ellison, How does the Market Use Citation Data? The Hirsch Index in Economics, September 2010

3189 Barbara Hanel and Regina T. Riphahn, The Employment of Mothers - Recent Developments and their Determinants in East and West Germany, September 2010

3190 Alexander Haupt and Silke Uebelmesser, Integration, Mobility, and Human Capital Formation, September 2010

3191 Vincenzo Galasso and Paola Profeta, When the State Mirrors the Family: The Design of Pension Systems, September 2010

3192 Stéphane Zuber and Geir B. Asheim, Justifying Social Discounting: The RankDiscounted Utilitarian Approach, September 2010

3193 Alexander Kemnitz, Educational Federalism and the Quality Effects of Tuition Fees, September 2010

3194 Claudia M. Buch, Sandra Eickmeier and Esteban Prieto, Macroeconomic Factors and Micro-Level Bank Risk, September 2010

3195 May Elsayyad and Kai A. Konrad, Fighting Multiple Tax Havens, September 2010

3196 Laszlo Goerke and Markus Pannenberg, Trade Union Membership and Dismissals, September 2010 
3197 Ferdinand Mittermaier and Johannes Rincke, Do Countries Compensate Firms for International Wage Differentials?, September 2010

3198 John Boyd, Gianni De Nicoló and Abu M. Jalal, Bank Competition, Asset Allocations and Risk of Failure: An Empirical Investigation, September 2010

3199 Guido Heineck and Bernd Süssmuth, A Different Look at Lenin’s Legacy: Trust, Risk, Fairness and Cooperativeness in the two Germanies, September 2010

3200 Ingvild Almås, Tarjei Havnes and Magne Mogstad, Baby Booming Inequality? Demographic Change and Earnings Inequality in Norway, 1967-2000, October 2010

3201 Thomas Aronsson and Sören Blomquist, The Standard Deviation of Life-Length, Retirement Incentives, and Optimal Pension Design, October 2010

3202 Thorvaldur Gylfason and Eduard Hochreiter, Growing Together: Croatia and Latvia, October 2010

3203 Ken Burdett and Melvyn Coles, Tenure and Experience Effects on Wages: A Theory, October 2010

3204 Wendy Carlin, Good Institutions are not enough: Ongoing Challenges of East German Development, October 2010

3205 Tobias König and Andreas Wagener, Tax Structure and Government Expenditures under Tax Equity Norms, October 2010

3206 Daniel W. Sacks, Betsey Stevenson and Justin Wolfers, Subjective Well-Being, Income, Economic Development and Growth, October 2010

3207 Mario Larch and Wolfgang Lechthaler, Why "Buy American” is a Bad Idea but Politicians still Like it, October 2010

3208 Guglielmo Maria Caporale and Luis A. Gil-Alana, US Disposable Personal Income and Housing Price Index: A Fractional Integration Analysis, October 2010

3209 Bruno S. Frey, Withering Academia?, October 2010

3210 Eva Mörk, Anna Sjögren and Helena Svaleryd, Childcare Costs and the Demand for Children - Evidence from a Nationwide Reform, October 2010

3211 Dan Kovenock, Brian Roberson and Roman M. Sheremeta, The Attack and Defense of Weakest-Link Networks, October 2010

3212 Shmuel Nitzan and Kaoru Ueda, Prize Sharing in Collective Contests, October 2010

3213 Erling Eide, Kristine von Simson and Steinar Strøm, Rank Dependent Utility, Tax Evasion and Labor Supply, October 2010 